\title{
SIMULATION OF RUN-OFF FROM THE GREENLAND ICE SHEET FOR PLANNING HYDRO-ELECTRIC POWER, ILULISSAT/JAKOBSHAVN, WEST GREENLAND
}

\author{
by
}

\author{
Roger J. Braithwaite and Henrik Højmark Thomsen
}

(Grønlands Geologiske Undersøgelse, Øster Voldgade 10, DK-1350 København K, Denmark)

\begin{abstract}
Simulations of run-off from the Greenland ice sheet were made as part of a feasibility study for provision of hydroelectric power for Ilulissat/Jakobshavn, West Greenland. The aims were to see if the available short series of run-off measurements are typical of those under present climatic conditions, and to assess possible changes in run-off likely to be caused by gross changes in drainage pattern on the ice sheet. Specific run-off was calculated from climatological data, whilst run-off volumes were calculated by integrating specific run-off over the area of the ice sheet. There have been substantial year-to-year variations in run-off, but the 6 year measurement period is reasonably representative of present climatic conditions. Run-off could be reduced by $21 \%$ as a result of changes in hydraulic conditions on the ice sheet without this having a significant effect on the economy of the planned hydro-electric power station.
\end{abstract}

\section{INTRODUCTION}

Simulations of run-off from the Greenland ice sheet at Paakitsup Akuliarusersua, about $45 \mathrm{~km}$ north-east of Ilulissat, West Greenland (position shown on map in Thomsen and others, 1989, this volume), were carried out as part of a feasibility study for the provision of hydro-electric power. The work was done in autumn 1986 (Thomsen and others, unpublished) at the request of the Greenland Technical Organization (GTO), to find out if the available short series of run-off measurements represented run-off conditions for the present climatic conditions, and to assess possible changes in run-off which might arise from gross changes in drainage pattern on, in, and under the ice sheet. In contrast, an earlier simulation by Braithwaite and Thomsen (1984) addressed only the first aim.

The simulations were performed using the mass balance (MB1) and run-off (ROI) models developed by Braithwaite $(1980,1984)$. The operation of these models is illustrated by the flow-diagram in Figure 1. The MBI model calculates specific run-off from climatological data, and the RO1 model combines this with the area distribution of the basin to give run-off volumes. The layout in Figure 1 is unusual in that the simulation of run-off volume is performed in two separate steps instead of by directly fitting observed run-off volumes to climatological data, as in more conventional models such as the modified NAM-II model used by the GTO (Thomsen and Jørgensen, 1984). This means that the model can be used either as a regional model or as a site-specific model, depending upon whether measured data is available for the calibration of the model.

The delineation of drainage boundaries on the ice sheet was the most difficult part of the glaciological work at Paakitsup Akuliarusersua because drainage occurs on, within, and under the ice (Thomsen and Braithwaite, 1987). The possible area distributions on the ice sheet used in the present simulation are based on studies of glacier hydraulics by Thomsen and others (1989, this volume).

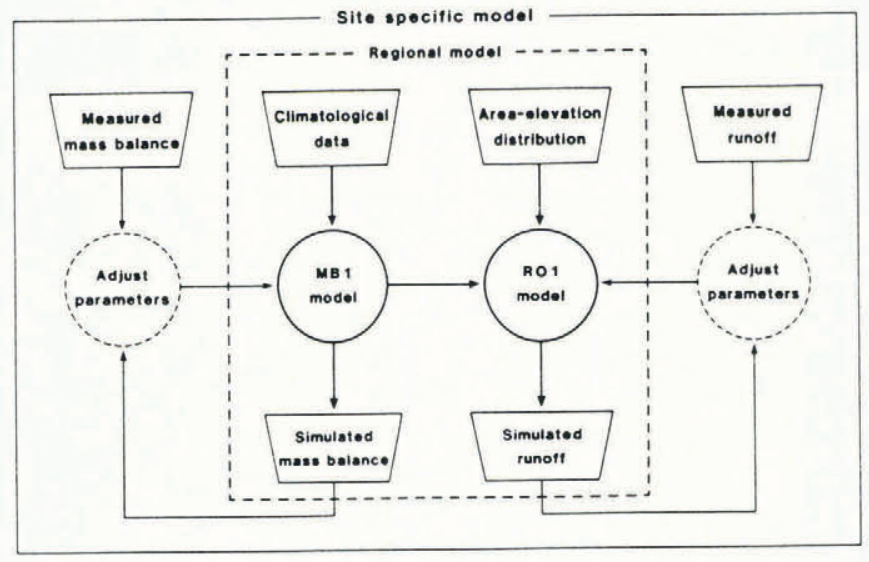

Fig. 1. Simplified flow-diagram illustrating the simulation of glacier run-off by use of the MBI/ROI models.

\section{DATA}

Run-off measurements were started by the GTO at Paakitsup Akuliarusersua in 1980, after the basin was identified as a possible source of hydroelectric power. Water levels were recorded in an outlet from a lake (Sø 187) and transformed into run-off by a rating curve based upon many simultaneous readings of discharge and water level. Detailed summaries of data are found in GTO (1986). Sø 187 is fed by run-off from two other lakes (Sø 233 and Sø $326)$, see map in Thomsen and others (1989, this volume), so that observed data refer to the combined run-off from these three sub-basins. However, separate measurements of water levels in Sø 233 and Sø 326 were started in 1985 and 1984 respectively and these indicate that over half the total run-off is routed through Sø 233 and only about 5\% is routed through Sø 326.

Hydrological measurements are difficult under arctic conditions and there are periods when recorders fail and missing data must be estimated. A summary of the annual run-off data from Sø 187 for $1980-85$ is given in Table I, which shows the measured (Obs.) and estimated (Est.) amounts of water. The estimates are made by the GTO as a part of their routine data analysis, initially subjectively but latterly more objectively using the modified NAM-II model (Thomsen and Jørgensen, 1984) to interpolate missing data. The mean run-off for the six-year period 1980-85 is $289 \times 10^{6} \mathrm{~m}^{3}$, but this figure is based upon only a short series of recordings including three years for which a substantial amount of data is missing. There may therefore be large errors in the run-off data presented.

Climatological data has been collected at Ilulissat since 1873, and is reasonably well documented for the period 1961-81 in annual summaries published by the Danish Meteorological Institute. However, monthly temperature and precipitation data for most of the 1980-85 run-off period 
TABLE I. ANNUAL RUN-OFF AT PAAKITSUP AKULIARUSERSUA WITH ANNUAL PRECIPITATION AND SUMMER MEAN TEMPERATURE IN ILULISSAT

Year

$\begin{array}{rr} & \text { Obs. } \\ 1980 & 212 \\ 1981 & 289 \\ 1982 & 261 \\ 1983 & 96 \\ 1984 & 301 \\ 1985 & 334\end{array}$

$$
\text { all values } \times 10^{6} \mathrm{~m}^{3}
$$$$
\text { bs. }+ \text { Est. }=\text { Total }
$$$$
103
$$$$
\begin{array}{r}
103 \\
63
\end{array}
$$$$
0
$$$$
75
$$$$
0
$$

Means:

$1980-85$

$1961-85$
249

40

$-$
Precipitation

Temperature could only be obtained in an unpublished and partially analysed form. Compared with other Greenland stations, data from Ilulissat has declined in quality, with observations for only certain synoptic hours and, most recently, only for working days. Despite these problems the 1980-84 data used here is probably quite reliable, although the 1985 data is still regarded as provisional.

For comparison with the run-off data, annual (September-August) total precipitation and summer (June-August) mean temperature in Ilulissat are given in Table I. There is a strong positive correlation $(r=+0.90)$ between annual run-off and summer temperature, and a weaker negative correlation $(r=-0.75)$ between annual run-off and annual precipitation (both significant at the $5 \%$ level). According to Collins (1985), and Braithwaite and Olesen (1988), this pattern of correlation is characteristic of a basin with a large amount of glacier cover.

Mean values of run-off, precipitation and temperature are given in Table I for the six-year period 1980-85, and for precipitation and temperature during the longer period 1961-85. As the values of mean precipitation and temperature for the two periods are almost the same it can be concluded that the period of run-off measurements is representative of run-off occurring during the last 25 years.

\section{MASS-BALANCE SIMULATION}

The MB1 model uses extrapolated monthly data for air temperature and precipitation from Ilulissat to calculate mass balance and specific run-off as functions of elevation within the basin. Monthly totals for the different balance elements are summed to give annual values at each elevation for an assumed hydrological year from September to August. The specific annual run-off is calculated as the sum of annual ablation (of ice and snow) and rainfall after allowing for possible effects of refreezing.

Temperatures recorded at Ilulissat are extrapolated to obtain values for the ice sheet by taking account of the inland heating between coast and ice sheet, the vertical temperature lapse, and the cooling effects between ice-free and ice-covered areas. Parameters describing these effects are either taken from glacier-climate studies at Qamanârssûp sermia (Braithwaite, 1984b) or are found by trial and error. For example, the calculated mass balance overestimates ablation if the inland heating is assumed to be the same as for Qamanårssûp sermia (Braithwaite, 1983), but gives reasonable agreement between observed and calculated balances for an assumed inland heating effect of only $20 \%$ of the Qamanârssûp sermia value (Fig. 2).

The precipitation in the basin is assumed to be the same as in Ilulissat. The monthly precipitation is divided into sub-totals for rainfall and snowfall at each elevation by assuming that precipitation falls as snow with the same probability as the occurrence of below-freezing temperatures in the month concerned (Braithwaite, 1985). This assumption is preliminary and may need to be revised.

$\begin{array}{cr}\text { m water } & { }^{\circ} \mathrm{C} \\ 0.21 & 6.9 \\ 0.25 & 7.2 \\ 0.25 & 6.3 \\ 0.35 & 5.4 \\ 0.30 & 6.1 \\ 0.16 & 7.5\end{array}$

$\begin{array}{ll}0.25 & 6.6 \\ 0.26 & 6.6\end{array}$

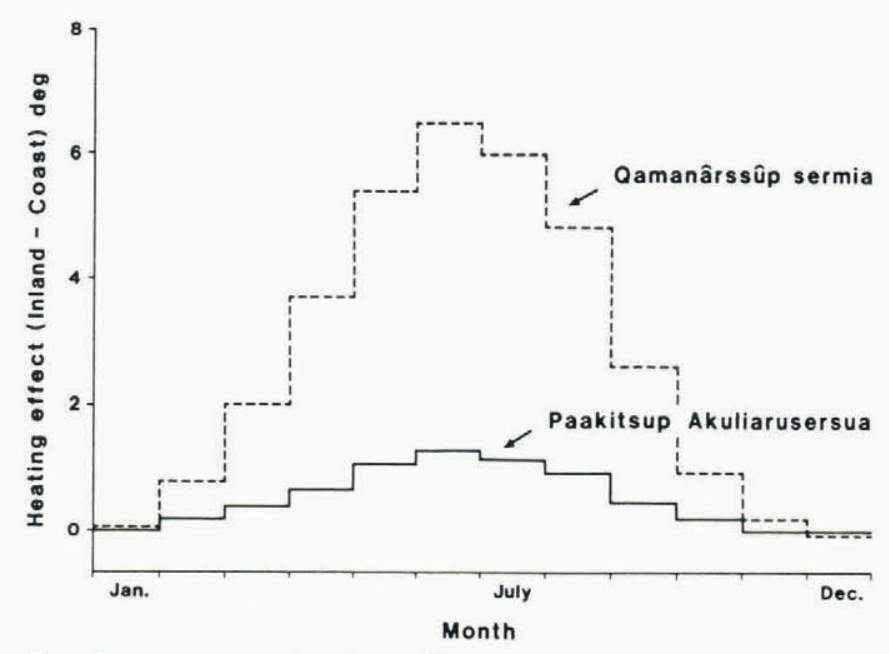

Fig. 2. Assumed heating effect between the coast and Paakitsup Akuliarusersua.

Monthly ablation of ice and snow at each elevation is assumed to be proportional to the corresponding monthly positive temperature sum, which is calculated from the monthly mean temperature value by the method of Braithwaite (1985). The curve in Figure 3 shows the assumed relationship between monthly ablation and monthly mean temperature, which is based on detailed glacier-climate studies at Nordbogletscher and Qamanârssûp sermia (Braithwaite and Olesen, 1985, 1989). The relationship is strictly valid only for ice surfaces but is applied in the present case because snow cover is sparse. Future versions of the model will take account of different ablation rates for ice and snow surfaces at the same temperatures (Braithwaite and Olesen, in press).

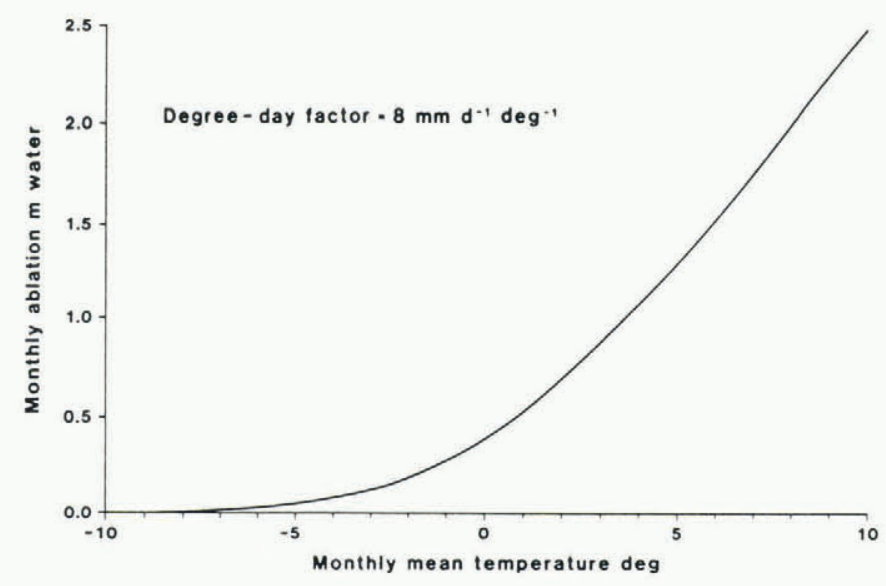

Fig. 3. Monthly ablation as a function (assumed) of monthly mean temperature. 


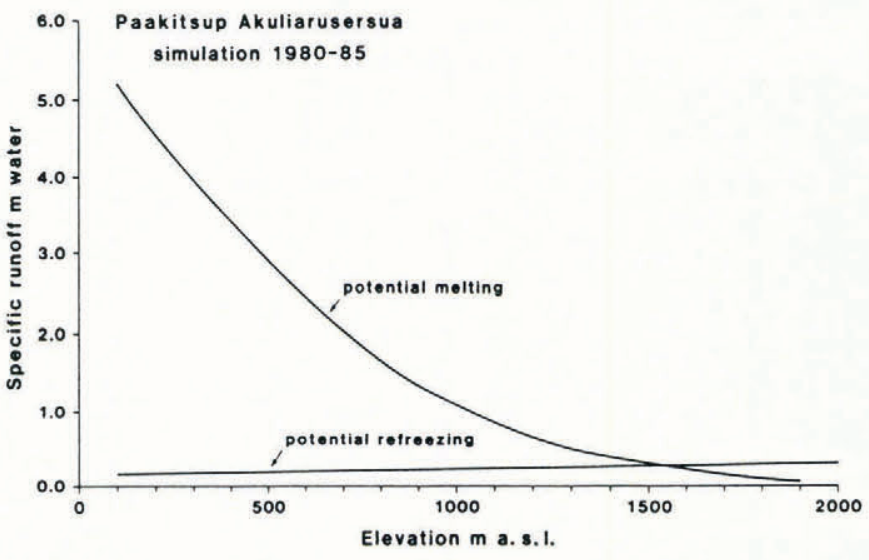

Fig. 4. Relationship between potential melting and potential refreezing for run-off simulation at Paakitsup Akuliarusersua.

In the present model new snow is added to the glacier surface, which may be either bare ice or old snow. Simulated melt water and rainfall are absorbed by refreezing into any snow cover until the snow density reaches a specified critical value, after which run-off is allowed to occur. Figure 4 shows the potential melting (with no refreezing) and the potential refreezing (strongest refreezing) as functions of elevation. The simulated run-off line, where potential refreezing equals potential melting, is at about $1500 \mathrm{~m}$ a.s.l.

Mass balance measurements have been made since 1982 (Thomsen, 1984) and the best agreement between observed and calculated annual balances is achieved with strong refreezing and the inland heating effect already shown in Figure 2. This agreement is illustrated in Figure 5 for the two years 1982-83 and 1983-84, while the agreement for 1984-85 (not shown) is not so good because the model overestimates ablation. This may be due to the low quality of the available climate data for 1985 .

\section{RUN-OFF SIMULATION}

The calculated specific run-off from the MB1 model is integrated over the assumed glacier area by the RO1 model so that it becomes possible to calculate the glacier run-off volume. The run-off from the glacier-free part of the basin is calculated as the product of the glacier-free area $\left(33 \mathrm{~km}^{2}\right)$ and the annual precipitation in Ilulissat. It is small compared with the glacier run-off, with a mean of $8 \times 10^{6} \mathrm{~m}^{3}$ for the 6 year period.

The RO1 calculation was repeated for all possible area configurations of the glacier basin identified by Thomsen and others (1989, this volume) which correspond to different values of an hydraulic parameter, $k$ (Björnsson, 1982). In all, simulations were made for 25 different conformations of the basin.

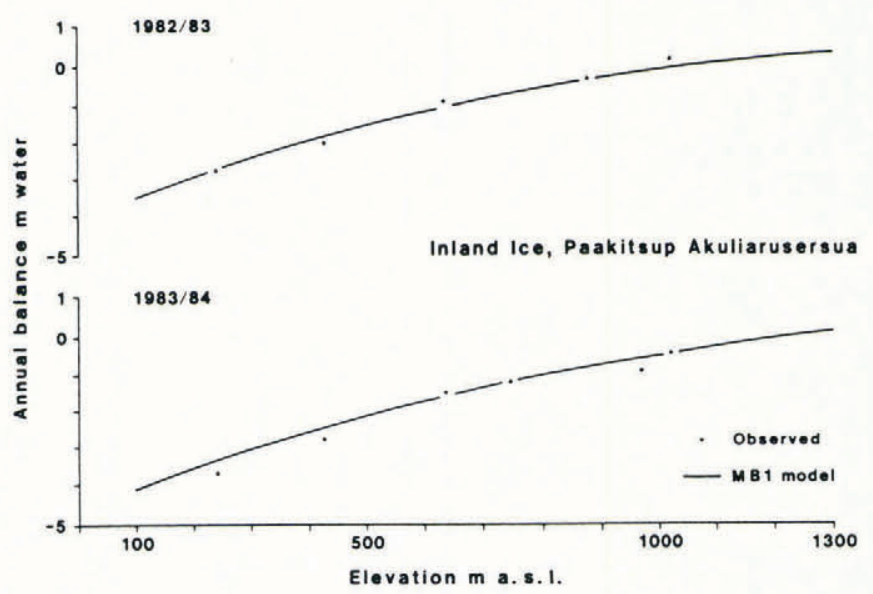

Fig. 5. Comparison between observed and simulated annual balances at Paakitsup Akuliarusersua.

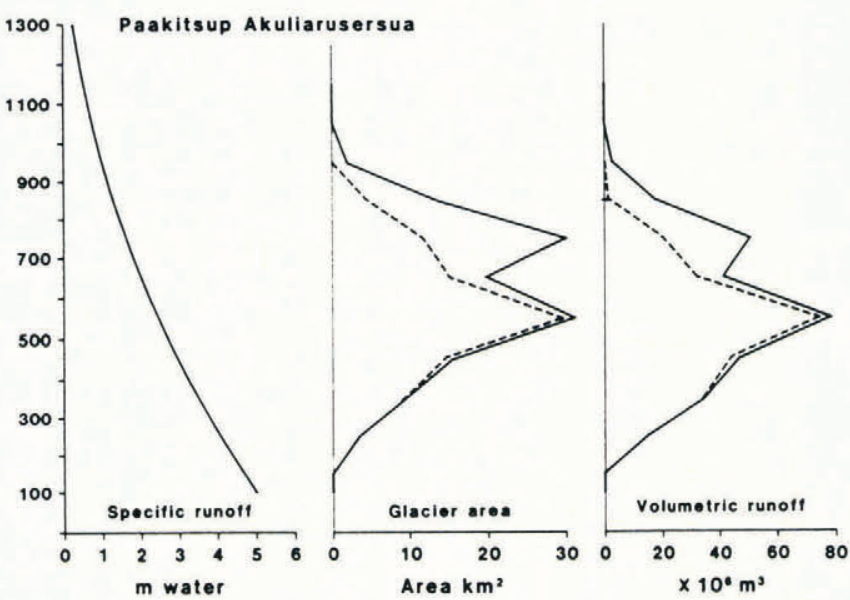

Fig. 6. Calculation of volumetric run-off from specific run-off values and glacier area.

The principle of the calculation has been illustrated by the example in Figure 6, where a single curve for specific run-off values plotted against elevation is applied to two different area distributions for the glacier cover in the basin. The specific run-off curve refers to the calculated mean for 1980-85, while the two area distributions are those for $k=0.7$ and $k=0.0$ respectively (Thomsen and others, 1989, this volume). In the latter case the resulting volumetric run-off decreases rapidly above $600 \mathrm{~m}$ a.s.l., whilst in the former case a substantial amount of run-off originates from around $800 \mathrm{~m}$ a.s.l. In both cases the basins terminate well below the run-off line.

\section{RESULTS}

The calculated run-off volumes for 1980-85 range from $337 \times 10^{6} \mathrm{~m}^{3}$, for $k=1.0$, to only $227 \times 10^{6} \mathrm{~m}^{3}$ for the most pessimistic interpretation with $k=0.0$, that is a range of $+17 \%$ to $-21 \%$ of the mean observed run-off of $289 \times 10^{6} \mathrm{~m}^{3}$. The best agreement between run-off observations and model is for $k=0.7$. This simulation for the 25 -year period $1961-85$ is illustrated in Figure 7. Run-off varies from year to year but the mean run-off for the six-year period of our measurements was only $3 \%$ less than the 25-year average, indicating that the measurement period is reasonably representative of the whole. Braithwaite and Thomsen (1984) came to a similar conclusion for the measurement period 1980-83, but also extended the simulation back to 1880 using old temperature records for Ilulissat. Although there were substantial decade-to-decade variations in run-off, culminating in high values in the $1930 \mathrm{~s}$ and 1950s, these cancel each other out over long periods so that the calculated 100-year-mean run-off is not greatly different from the present run-off value.

The above discussion refers to run-off variations with a constant basin area. Braithwaite and Thomsen (1984) have

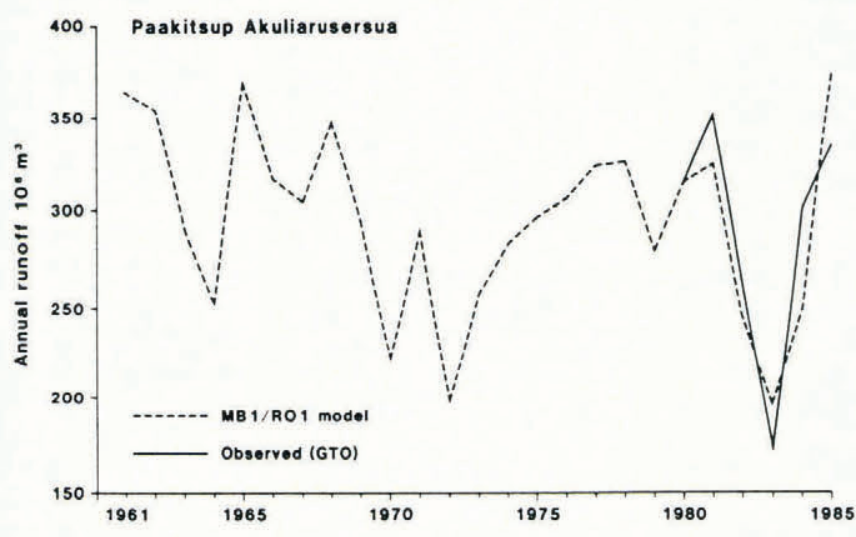

Fig. 7. Simulated run-off variations at Paktisup Akuliarusersua for a 25 year period. 
shown that the known retreat of the ice margin since the last century would only have reduced mean run-off by $0.7 \%$ per year, which is negligible compared with year-to-year variations of $\pm 23 \%$ of mean run-off. However, even if climate remains constant run-off may change as the result of changes in hydraulic conditions, such as a change in the value of $k$. If the present $k$ value is 0.7 with a model mean run-off of $287 \times 10^{6} \mathrm{~m}^{3}$, then the worst that can happen in the future is that the basin will change to a configuration for which $k=0.0$. In this case the model prediction for run-off will be reduced by $21 \%$ to $227 \times 10^{6} \mathrm{~m}^{3}$.

\section{OUTLOOK}

The likelihood of hydraulic change cannot yet be assessed, but detailed investigations of glacier hydraulics have been started at Paakitsup Akuliarusersua (Thomsen and others, 1989, this volume) in order to study the problem. It is thought that even a possible reduction of $21 \%$ in run-off would have little effect on the economy of a hydro-electric power station in this area because the reservoir input-output relationship is non-linear, and the remaining $79 \%$ of run-off would be enough to generate the high-cost electricity needed for lighting and power.

Improved modelling of the glacier-climate relationship could lead to better run-off simulations and thereby to improvements in the design of the hydro-electric power station, and to the better run-off forecasts important for the operation of the station if it is ever built. Research and data collection should therefore continue; the present hydrological uncertainties of a few per cent are smaller than the uncertainties surrounding economic factors like future oil prices and interest rates.

\section{ACKNOWLEDGEMENTS}

This paper is published by permission of the Director, the Geological Survey of Greenland. The work is part of a feasibility study for the production of hydro-electric power for Ilulissat, which was partly funded by the European Economic Community (EEC) through the European Regional Development Fund, and partly by the former Ministry for Greenland, Denmark.

\section{REFERENCES}

Björnsson, H. 1982. Drainage basins on Vatnajökull mapped by radio echo soundings. Nord. Hydrol., 13(4), 213-232.
Braithwaite, R.J. 1980. Regional modelling of ablation in West Greenland. Gronl. Geol. Undersogelse. Rapp. 98.

Braithwaite, R.J. 1983. Comparisons between automatic and manual climate stations at Qamanârssûp sermia. Gronl. Geol. Undersogelse Gletscher-Hydrol. Medd. 83/5.

Braithwaite, R.J. 1984a. Glaciological and climatological investigations at Qamanârssûp sermia, West Greenland. Gron. Geol. Undersogelse. Rapp. 120, 109-112.

Braithwaite, R.J. 1984b. Hydrological modelling in Greenland in connection with hydropower. Gron. Geol. Undersogelse. Rapp. 120, 90-94.

Braithwaite, R.J. 1985. Calculation of degree-days for glacier-climate research. Z. Gletscherkd. Glazialgeol., 20, $1984,1-8$.

Braithwaite, R.J. and O.B. Olesen. 1985. Ice ablation in West Greenland in relation to air temperature and global radiation. Z. Gletscherkd. Glazialgeol., 20, 1984, 155-168.

Braithwaite, R.J. and O.B. Olesen. 1988. Effect of glaciers on annual run-off, Johan Dahl Land, south Greenland. J. Glaciol., 34(117), 200-207.

Braithwaite, R.J. and O.B. Olesen. 1989. Calculation of glacier ablation from air temperature, West Greenland. In Oerlemans, J., ed. Glacier Fluctuations and Climatic Change. Proceedings of the Symposium on glacier Fluctuations and Climatic Change, held in Amsterdam, I-5 June 1987. Dordrecht, etc., Kluwer Academic Publishers, 219-233.

Braithwaite, R.J. and O.B. Olesen. In press. Winter accumulation reduces summer ablation on Nordbogletscher, south Greenland. Z. Gletscherkd. Glazialgeol.

Braithwaite, R.J. and H.H. Thomsen. 1984. Run-off conditions at Pakitsup Akuliarusersua, Jakobshavn, estimated by modelling. Gron. Geol. Undersogelse. Gletscher-Hydrol. Medd. 84/3.

Collins, D.N. 1985. Climatic variation and runoff from Alpine glaciers. Z. Gletscherkd. Glazialgeol., 20, 1984, 127-145.

Thomsen, H.H. 1984. Mass balance measurements at the margin of the inland ice near Jakobshavn, West Greenland. Polarforschung, 54(1), 37-41.

Thomsen, H.H. and R.J. Braithwaite. 1987. Use of remote-sensing data in modelling run-off from the Greenland ice sheet. Ann. Glaciol., 9, 215-217.

Thomsen, H.H., L. Thorning, and R.J. Braithwaite. Unpublished. Vurdering af de gletscher-hydrologiske forhold pâ indlandsisen ved Paakitsup Akuliarusersua, Ilulissat/Jakobshavn. Grønlands Geologiske Undersøgelse. Arbejdsnotat.

Thomsen, H.H., L. Thorning and O.B. Olesen. 1989. Applied glacier research for planning hydro-electric power, Jakobshavn/Ilulissat, West Greenland. Ann. Glaciol., 13, 257-261.

Thomsen, T. and G.H. Jørgensen. 1984. Hydrological data-work in Greenland. Nord. Hydrol., 15, 39-56. 